\title{
The first European representative of the South American family Xenopteraidae discovered in the Guadalupian of Lodève (France) (Insecta: Megasecoptera)
}

André Nel, Jean Lapeyrie \& Romain Garrouste

Nel, A., LAPEyrie, J. \& GARRouste, R., 2018. The first European representative of the South American Xenopteraidae discovered in the Guadalupian of Lodève (France) (Insecta : Megasecoptera). Alcheringa $X X X, \mathrm{xxx}-\mathrm{xxx}$.

A new genus, Sinitshenkovae gen. nov., is described, comprising the Carboniferous species Sinitshenkovae hueneckeni (Pinto \& Pinto de Ornellas, 1978) comb. nov. from South America and new Guadalupian species S. gallica sp. nov. from France. These two species are attributed to the Paleozoic South American family Xenopteraidae, a previously monospecific family only containing Xenoptera riojaensis Pinto, 1986. Sinitshenkovae gallica sp. nov. is therefore the youngest representative of this family and the only record outside South America, which suggests that our current knowledge of the palaeobiogeography of Permian and Carboniferous insects remains incomplete.

André Nel [anel@mnhn.fr] and Romain Garrouste [garroust@mnhn.fr], Institut Systématique Evolution Biodiversité (ISYEB), Muséum national d'Histoire naturelle, CNRS, Sorbonne Université, EPHE, 57 rue Cuvier, CP 50, 75005 Paris, France. Jean Lapeyrie [jean.lapeyrie@orange.fr], Corniche de Fontbonne, F-34700Lodève, France. 
Keywords: Palaeodictyopteroida, gen. \& sp. nov., Guadalupian, Permian, France.

OVER the last 18 years, a number of discoveries from the Guadalupian (locally known as the 'Red' Permian) of southern France have demonstrated the presence of a rich entomofauna, despite previous studies suggesting that these playa outcrops contained only ichnofossils. Although numerous sites in both the Alpes-Maritimes and Var Departments have yielded a range of fossil insects illustrating trophic relationships between plants, insects and their predators in the Paleozoic (Garrouste et al. 2016), those in the Lodève Basin have proven the richest in terms of fossil insect diversity and abundance, with more than 65 different species and 13 orders recorded, most of which were collected by one of the present authors (JL) (Prokop \& Nel 2011, Prokop et al. 2015a,b, 2017, Garrouste et al. 2018). Although the Paleozoic orders Palaoedictyoptera and Diaphanopterodea are certainly present, and in the case of the Diaphanopterodea, relatively diverse, within the Lodève Basin, records of the related order Megasecoptera remained unknown until now. Here we describe the first megasecopteran from the Permian of the Lodève Basin, based on an incomplete wing. This wing is noted to be similar to species of the Carboniferous South American family Xenopteraidae Ross, Nicholson \& Jarzembowski, 2013.

\section{Material and methods}

The fossil was collected by one of the authors (JL) from 'Canals' outcrop in the Guadalupian, Permian Lodève Basin. It is deposited in Lapyerie collection, Musée of Lodève (Ld LaP).

The wing was studied under a NIKON SMZ 1500 binocular microscope, and photographed using a NIKON D800; photographs were processed using the image-editing software Adobe Photoshop CS. Line drawings of the venation were prepared directly with the aid of a camera lucida. 
Wing venation nomenclature follows that of Kukalová-Peck (1991), with abbreviations as follows: AA — anal anterior; AP — anal posterior; $\mathrm{C}$ - costal vein; $\mathrm{CuA}$ - cubitus anterior; $\mathrm{CuP}$ - cubitus posterior; MA — media anterior; MP - media posterior; $\mathrm{m}$-cua — basal brace between $\mathrm{M}$ and $\mathrm{CuA}$; $\mathrm{RA}$ - radius anterior; $\mathrm{RP}$ - radius posterior; $\mathrm{ScP}$ - subcostal posterior.

\section{Systematic palaeontology}

Class INSECTA Linnaeus, 1758

Infraclass PALAEOPTERA Martynov, 1923

Superorder PALAEODICTYOPTEROIDA Goldenberg, 1877

Order MEGASECOPTERA Brongniart, 1885

Family XENOPTERAIDAE Ross, Nicholson \& Jarzembowski, 2013

Type genus. Xenoptera Pinto, 1986

Remarks. Xenopteraidae Ross, Nicholson \& Jarzembowski, 2013 was proposed as a replacement name for the fossil family 'Xenopteridae Pinto, 1986', as this name was preoccupied by Xenopteridae Riek, 1955 (order Orthoptera; type genus Xenopterum Riek, 1955).

Sinitshenkovae gen. nov.

Etymology. Named after our colleague N.D. Sinitshenkova, specialist of Palaeodictyopterida. 
Species included. Sinitshenkovae hueneckeni (Pinto \& Pinto de Ornellas, 1978) (formerly 'Philiasptilon' hueneckeni Pinto \& Pinto de Ornellas, 1978); Sinitshenkovea gallica sp. nov.

Diagnosis. Fore wing characters only. A rather broader area between RA and C; veinlets between main veins very oblique and distinctly sigmoidal.

\section{Sinitshenkovae gallica sp. nov.}

(Fig. 1)

Diagnosis. Veinlets between RA and C distinctly oblique and long; few veinlets between main veins; three posterior branches of RP.

Etymology. From 'Gallia', the Latin name for France.

Holotype. Specimen Ld LaP 760, (counterprint), Lapeyrie collection, Musée Fleury, Lodève, France.

Locality and age. Guadalupian (mid-Permian) Mérifons Member, Salagou Formation; ‘Canals’ outcrop (see Garric 2000), near Lodève, Hérault, France.

\section{Description}

Counterimprint of the distal half of an elongate wing, fragment $15.6 \mathrm{~mm}$ long, $4.9 \mathrm{~mm}$ wide. Concave ScP ending on costal margin $7.5 \mathrm{~mm}$ from wing apex; subcostal space $0.4 \mathrm{~mm}$ wide, 
one preserved veinlet between ScP and C. Convex RA weakly curved, area between it and $\mathrm{C}+\mathrm{ScP} 0.6 \mathrm{~mm}$ wide, with 6-7 hort oblique and simple veinlets; RA ending $1.0 \mathrm{~mm}$ from wing apex; base of RP not preserved, but at least $12 \mathrm{~mm}$ from wing apex; concave RP with three simple branches. Strongly convex MA simple, strongly approaching RP basally; concave MP forking into two long posterior branches; bases of MA and MP not preserved; area between MP and $\mathrm{CuA}$ with a long oblique crossvein partly preserved (brace $\mathrm{m}-\mathrm{cua}$ ?). Distinctly convex CuA nearly straight and simple, with a broad area between it and CuP, equal in width to area between MA and MP; concave CuP simple and nearly straight. Two convex (AA1 and AA2) and one concave (AP) straight anal veins. Few crossveins between RP, MA, MP, and CuA, all long, oblique and sigmoidally curved; additional 'convex veins' running alongside $\mathrm{CuP}, \mathrm{AA} 1$, and $\mathrm{AA} 2$, and which cross the transverse veinlets between $\mathrm{CuA}$ and $\mathrm{CuP}$ and $\mathrm{CuP}$ and $\mathrm{AA} 1$, appear to be fossilization artifacts.

\section{Discussion}

Sinitshenkovae gallica sp. nov. does not resemble any of the previously described insects from the Permian Lodève Basin, differing in its forked MP, simple MA and $\mathrm{CuA}$, and sigmoidal crossveins (Prokop \& Nel 2011, Prokop et al. 2015a,b, Garrouste et al. 2018).

The lack of information on the basal half of the wing makes the fossil difficult to attribute to any particular taxon. Although some 'Grylloblattodea' and 'Eoblattida' share the short ScP, pectinate RA, and simple MA seen in this fossil, they generally also have multi-branched CuA (e.g. Tshekardembia Novokshonov, 1995, Nestorembia Shcherbakov 2015; Storozhenko 1998, Aristov 2017a,b), and as a result Sinitshenkovae gallica is excluded from these orders.

Like the new fossil described here, the Caloneurodea also have few RP and M branches, and $\mathrm{CuA}$ and $\mathrm{CuP}$ strongly converging, closely parallel. Although the 'vein' seen alongside $\mathrm{CuP}$ in Sinitshenkovae gallica could be interpreted as a $\mathrm{CuA}$ closely parallel to $\mathrm{CuP}$, the 
presence of similar 'veins' along AA1 and AA2, plus the fact that this feature crosses a veinlet between $\mathrm{CuA}$ and $\mathrm{CuP}$, strongly suggests it is not a true vein. Furthermore, an attribution to the Caloneurodea is unlikely because in this group the median vein is either simple or has only one or two distal branches; these insects do not have M separating basally into a convex MA and a concave MP, as seen in Sinitshenkovae gallica. An alternative interpretation of the wing venation could be proposed for our fossil that would be more its venation congruent with an attribution to the Caloneurodea; viz., the vein we name MA could be a basal branch of RP, making the forked vein posterior to this (our MP) MA and the vein after that (our $\mathrm{CuA}) \mathrm{MP}+\mathrm{CuA}+\mathrm{CuPa} \alpha$ in accordance with Béthoux et al. (2003). However, this alternative hypothesis is in contradiction with the fact that the basal branch of RP (our MA) would then be distinctly convex, which is unlikely as the other branches of RP are concave. This would also indicate a very broad area between the veins ' $\mathrm{MP}+\mathrm{CuA}+\mathrm{CuPa} \alpha$ ' (our $\mathrm{CuA}$ ) and $\mathrm{CuP}$ in Sinitshenkovae gallica, whereas this area is very narrow in Caloneurodea. Thus we reject the hypothesis of an attribution to the Caloneurodea for this new species.

Some Megasecoptera have a relatively short ScP and a distal area between RA and C with short veinlets (viz. Eubrodia Carpenter, 1967; Prokop et al. 2017) as seen in the new fossil, and some also share the long and oblique brace m-cua (viz. Calohymen Carpenter, 1947). Only a small number of megasecopterans share the following combination of characters: simple A, CuP, CuA, and MA; MP with only two branches; presence of few long sigmoidal crossveins. Further, the strong basal convergence of MA and RP seen in Sinitshenkovae gallica is a character also present in the Megasecoptera. Sinitshenkova (2002) divided the Mischopterida Handlirsch, 1906 (= Megasecoptera Brongniart, $1893+$ Archodonata Martynov, 1932) into four suborders: Eubletina Laurentiaux, 1953, Mischopterina Handlirsch, 1906 ('essentially the same as that previously called Eumegasecoptera'; Sinitshenkova 2002, 
p. 121, Aspidothoracina Handlirsch, 1919, and Permothemistina Martynov, 1935. The present fossil is excluded from Sinitshenkova's Permothemistina as insects of this suborder have a pterostigma and a branched $\mathrm{CuA}$. The 'Aspidothoracina' were described as follows: 'Aspidothoracinans are similar to Mischopterina in wings well elongate, costalised and petiolate, but synapomorphic in the wings further costalised (costal space practically lost, and C, SC, and R almost or well touching each other, or else SC lost' (Sinitshenkova 2002, p. 121). As the costal space is rather broad and $\mathrm{ScP}$ does not touch $\mathrm{R}$ in Sinitshenkovae gallica, an attribution to this group is also excluded. Finally, Sinitshenkova (2002, p. 121) characterized the 'Mischopterina' as 'synapomorphic in having the elongate body lacking paranota, the wings well costalised, homonomous, elongate (rather triangular in Mischopteridae) and usually petiolate, with usually single pectinate A, and crossveins arranged in transverse rows, and plesiomorphic in having well developed costal space and percurrent SC'. Sinitshenkovae gallica therefore differs from this group in the fact that it does not preserve pectinate anal veins, its wing is elongate but not triangular shaped, and in its crossveins being elongate and not clearly arranged into rows.

The Eubletina sensu Sinitshenkova (= Eubleptidae, Namurodiaphidae, Anchineuridae, Engisopteridae, Sphecorydaloididae, and 'Xenopteridae Pinto 1986', including 'Philiasptilon' hueneckeni Pinto \& Pinto de Ornellas, 1978) were characterized by 'the robust body, prothoracic paranota, wide costal space, wide wing base with 3 independent anal veins, and generally rich venation' (Sinitshenkova 2002, p. 121). Within the Eubletina, Sinitshenkovae gallica differs from the Eubletidae, Anchineuridae, Engisopteridae and Namurodiaphidae in having a shorter ScP, sigmoidal crossveins, and simple $\mathrm{CuA}$ and $\mathrm{CuP}$ (Carpenter 1963a, 1992, Kukalová-Peck 1975, Kukalová-Peck \& Brauckmann 1990). The Sphecorydaloididae share with Sinitshenkovae gallica the short ScP, but differ in the presence of short fusions of MA with RP and CuA with M, plus a forked CuP (Pinto 1994). 
Overall, the preserved venation of Sinitshenkovae gallica is most similar to the wings of Xenoptera riojaensis Pinto, 1986 and 'Philiasptilon' hueneckeni, sharing features such as the shortened ScP, short veinlets between RA and C, simple MA, single MP fork, and simple $\mathrm{CuA}, \mathrm{CuP}$ and anal veins. 'Philiasptilon' hueneckeni also shares the presence of long, oblique, sigmoidal crossveins, which are clearly visible in the photograph of the holotype (Pinto \& Pinto de Ornellas 1978, fig. 1), although this feature is not seen in Xenoptera (which has straight crossveins). Therefore, we attribute the new fossil to the family Xenopteraidae, but establish a new genus for Sinitshenkovae gallica and 'Philiasptilon' hueneckeni, which differs from Xenoptera primarily in the shape of the crossveins.

The type species of the diaphanopterid Philiasptilon Zalessky, 1931, Philiasptilon maculosum Zalessky, 1931, differs strongly from 'Philiasptilon' hueneckeni in having CuA with many branches (or perhaps MP with many branches, as following Zalessky's (1931) original interpretation, the vein $\mathrm{M}$ would be simple, which is rather unusual for these insects). Therefore, as already suggested by Sinitshenkova (2002), 'Philiasptilon' hueneckeni likely corresponds to a very different taxon and should be placed in a different genus, family, and order. We propose that the best place for this species is within the Xenopteraidae with Sinitshenkovae gallica.

Notice that Sinitshenkovae gallica has some similarities with the Brodiopteridae Carpenter, 1963 (genus Brodioptera Copeland, 1957), but it differs from Brodioptera in the presence of veinlets between $\mathrm{ScP}$ and $\mathrm{C}$, between RA and C+ScP, and a forked MP (Copeland 1957; Carpenter 1963b; Nelson \&Tidwell 1987; Pecharová et al. 2015).

\section{Conclusion}

This new discovery extends the range of the Xenopteraidae into the Permian of Europe for the first time, as xenopteraids were previously only known from the Late Carboniferous of South 
America. This indicates that this family was more widespread in time and space than previously interpreted. The case of the French 'red' Permian outcrops shows that any new

Middle or Late Permian entomofauna contains a majority of new taxa, either genera or species, even families. Important efforts shall be necessary in the next future to improve our vision and understanding of the Permian insect diversity, crucial to better estimate the impact of the Permian-Triassic crisis on this major clade.

\section{Data access statement}

This study did not involve any underlying data. The described specimen is available for restudy at the public institute indicated in the text.

\section{Acknowledgements}

We sincerely thank one anonymous referee and the editor of the journal of their helpful comments on the first version of the paper.

\section{Funding}

This work was supported by no external funding.

\section{References}

ARISTOV, D.S., 2017a. New insects (Insecta: Eoblattida, Embiida) from the Permian of Russia and the Triassic of Kyrgyzstan, with observations on the origin of webspinners. Paleontological Journal 51, 161-170.

ARISTOV, D.S., 2017b. Paleozoic evolution of the Insecta Gryllones. $\mathrm{PhD}$ thesis, Paleontological Institute Im. A.A. Borysyaka Russian Academy of Sciences Moscow, 238 pp. (unpublished) 
BÉthouX, O., Nel, A. \& LAPEyrie, J., 2003. The extinct order Caloneurodea (Insecta: Pterygota: Panorthoptera): wing venation, systematics and phylogenetic relationships. Annales Zoologici 54, 287-300.

BRONGNiART, C., 1885. Les insectes fossiles des terrains primaires. Coup d'oeil rapide sur la faune entomologique des terrains paléozoïques. Bulletin de la Société des Amis des Sciences Naturelles de Rouen (Series 3) 1885, 50-68.

BRONGNiART, C., 1893. Recherches pour servir à l'histoire des insectes fossiles des temps primaires précédées d'une étude sur la nervation des ailes des insectes. Bulletin de la Société d'Industrie Minérale de Saint-Etienne (Series 3) 7, 1-491.

CARPENTER, F.M., 1963a. A megasecopteron from Upper Carboniferous strata in Spain. Psyche 70, 44-49.

CARPenter, F.M., 1963b. Studies on North American Carboniferous insects. 2. The genus Brodioptera from the Maritime Province, Canada. Psyche 70, 59-63.

CARPenter, F.M., 1967. Studies on North American Carboniferous insects. Part 5. Palaeodictyoptera and Megasecoptera from Illinois and Tennessee with a discussion of the order Sypharopteroidea. Psyche 74, 58-84.

CARPenter, F.M., 1992. Studies of North American Carboniferous insects. Part 9. A new species of Eubleptidae from Mazon Creek (Palaeodictyoptera). Psyche 99, 147-152.

Copeland, M.J., 1957. The arthropod fauna of the Upper Carboniferous rocks of the Maritime Provinces. Memoirs of the Geological Survey of Canada 286, 1-110.

GARRIC, J., 2000. Les rigoles fossilifères du Saxonien du bassin de Lodève (Languedoc, France). Bulletin de la Société d'Histoire Naturelle d'Autun 174, 7-48.

Garrouste, R., Hugel, S., Jacquelin, L., Rostan, P., Steyer, J-S., DesutterGRANDCOLAS, L. \& NeL, A., 2016. Insect mimicry of plants dates back to the Permian. Nature Communications 7 (13735), 1-6. 
Garrouste, R., Lapeyrie, J., Steyer, J-S., Giner, S. \& Nel, A., 2018. Insects in the Red Middle Permian of Southern France: first Protanisoptera (Odonatoptera) and new Caloneurodea (Panorthoptera), with biostratigraphical implications. Historical Biology 30, $546-553$.

GoldenberG, F., 1877. Die fossilen Thiere aus der Steinkohlenformation von Saarbrücken. Fauna Saraepontana Fossilis 2, i-iv + 1-54.

HandliRsch, A., 1906-1908. Die fossilen Insekten und die Phylogenie der rezenten Formen. Ein Handbuch für Paläontologen und Zoologen. Engelman, V.W. publ., Leipzig, 1430 pp. HandliRSCH, A., 1919. Revision der paläozoischen Insekten. Denkschriften der Kaiserlichen Akademie der Wissenschaften, Mathematisch-Naturwissenschaftliche Klasse 96, 511-592.

KukalovÁ-Peck, J., 1975. Megasecoptera from the Lower Permian of Moravia. Psyche 82, $1-19$.

KuKALOVÁ-PeCK, J., 1991. Chapter 6: Fossil history and the evolution of hexapod structures. In The insects of Australia, a textbook for students and research workers (2nd edn). NAUMANN, I.D., ed., Melbourne University Press, Melbourne, 141-179.

KukAlovÁ-Peck, J. \& Brauckmann, C., 1990. Wing folding in pterygote insects, and the oldest Diaphanopterodea from the Early Carboniferous of West Germany. Canadian Journal of Zoology 68, 1104-1111.

LaurentiauX, D., 1953. Classe des insectes (Insecta Linné, 1758), pp. 397-527. In: Piveteau J. (ed.) Traité de Paléontologie, Masson (Publ.), Paris, 3.

LinNAEUS, C. von, 1758. Systema Naturae per regna tria naturae secundum classes, ordines, genera, species cum characteribus, differentiis, synonymis, locis. Ed. decima reformata. Holmiae, Laur. Salvii, 1, 1-823.

MARTYNOV, A.V., 1923. L'évolution de deux formes d'ailes différentes chez les insectes. Revue Zoologique Russe 4, 155-185. 
Martynov, A.V., 1935. Permian fossil insects from Arkhangelsk district. Part 5. Homoptera. Trudy Paleozoologicheskogo Instituta Akademii nauk SSSR 4, 1-35.

Nelson, C.R. \& Tidwell, W.D., 1987. Brodioptera stricklani n. sp. (Megasecoptera: Brodiopteridae), a new fossil insect from the upper Manning Canyon Shale Formation, Utah (Lowermost Namurian B). Psyche 94, 309-316.

NovoKshonov, V.G., 1995. New fossil insects from the Kungurian of Middle Ural. Paleontological Journal 29, 61-67.

PecharovÁ, M., Ren, D. \& Prokop, J., 2015. A new palaeodictyopteroid (Megasecoptera: Brodiopteridae) from the Early Pennsylvanian of northern China reveals unique morphological traits and intra-specific variability. Alcheringa: An Australasian Journal of Palaeontology 39, 236-249.

PINTO, I.D., 1986. Carboniferous insects from Argentina. 3. Family Xenopteridae Pinto nov. fam. (Megasecoptera). Pesquisas (Zoologia) 18, 23-29.

PINTO, I.D., 1994. Sphecorydaloides lucchesei, a new Carboniferous megasecopteran insect from Argentina. Pesquisas (Zoologia) 21, 85-89.

Pinto, I.D. \& Pinto DE ORnEllas, L., 1978. Upper Carboniferous insects from Argentina. 1. Familia Diaphanopteridae (Megasecopteroidea). Pesquisas (Zoologia) 10, 87-95.

Prokop, J. \& Nel, A., 2011. New Middle Permian palaeopteran insects from Lodève Basin in southern France (Ephemeroptera, Diaphanopterodea, Megasecoptera). ZooKeys 130, 4155.

Prokop, J., Fernandes, F.R., LAPEyrie, J. \& Nel, A., 2015a. Discovery of the first lacewings (Neuroptera: Permithonidae) from the Guadalupian of Lodève Basin (Southern France). Geobios 48, 263-270. 
Prokop, J., Szwedo, J., Lapeyrie, J., Garrouste, R. \& Nel, A., 2015b. New Middle Permian insects from Salagou Formation of the Lodève Basin in southern France (Insecta: Pterygota). Annales de la Société Entomologique de France (N.S.) 51, 14-51.

Prokop, J., Pecharová, M., Nel, A., Grey, M. \& Hörnschemeyer, T., 2017. A remarkable insect from the Pennsylvanian of the Joggins Formation in Nova Scotia, Canada: insights into unusual venation of Brodiidae and nymphs of Megasecoptera. Journal of Systematic Palaeontology 15, 1051-1065.

RIEK, E.F., 1955. Fossil insects from the Triassic beds at Mt. Crosby, Queensland. Australian Journal of Zoology 3, 654-691.

Ross, A.J., Nicholson, D.B. \& Jarzembowski, E.A., 2013. Omaliidae Handlirsch, 1904 (Insecta, Archaeorthoptera) and Xenopteridae Pinto, 1986 (Insecta, Megasecoptera): proposed emendation to Omaliaidae and Xenopteraidae respectively to remove homonymy with Omaliinae MacLeay, 1825 (Insecta, Coleoptera) and Xenopteridae Riek, 1955 (Insecta, Orthoptera). Bulletin of Zoological Nomenclature 70, 166-170.

ShCHERbAKOV, D.E., 2015. Permian and Triassic ancestors of webspinners (Embiodea). Russian Entomological Journal 24, 187-200.

SinITSHENKOVA, N.D., 2002. Chapter 2.2.1.2.3. Superorder Dictyoneurida Handlirsch, 1906 (= Palaeodictyopteroidea). In History of insects. RASNITSYN, A.P. \& QuiCKE, D.L.J., eds, Kluwer Academic Publishers, Dordrecht, 115-124.

StOROZHENKO, S.Yu., 1998. Sistematika, filogeniya i evolyutsiya grilloblattidovykh nasekomykh (Insecta: Grylloblattida) [Systematics, phylogeny and evolution of the grylloblattids (Insecta: Grylloblattida)]. Dal'nauka, Vladivostok, 1-207. (Russian)

ZALESSKY, M.D., 1931. Observations sur les insectes trouvés dans les dépôts à charbons du bassin de Kousnetzk et sur l'âge de ces derniers d'après la faune entomologique. Bulletin de la Société Géologique de France (Series 5) 1, 209-218. 
Fig. 1. Sinitshenkovae gallica gen \& sp. nov., holotype Ld LaP 760: A-B, photographs of wing under different angles. C, line drawing. Scale bar $=4 \mathrm{~mm}$. 
C

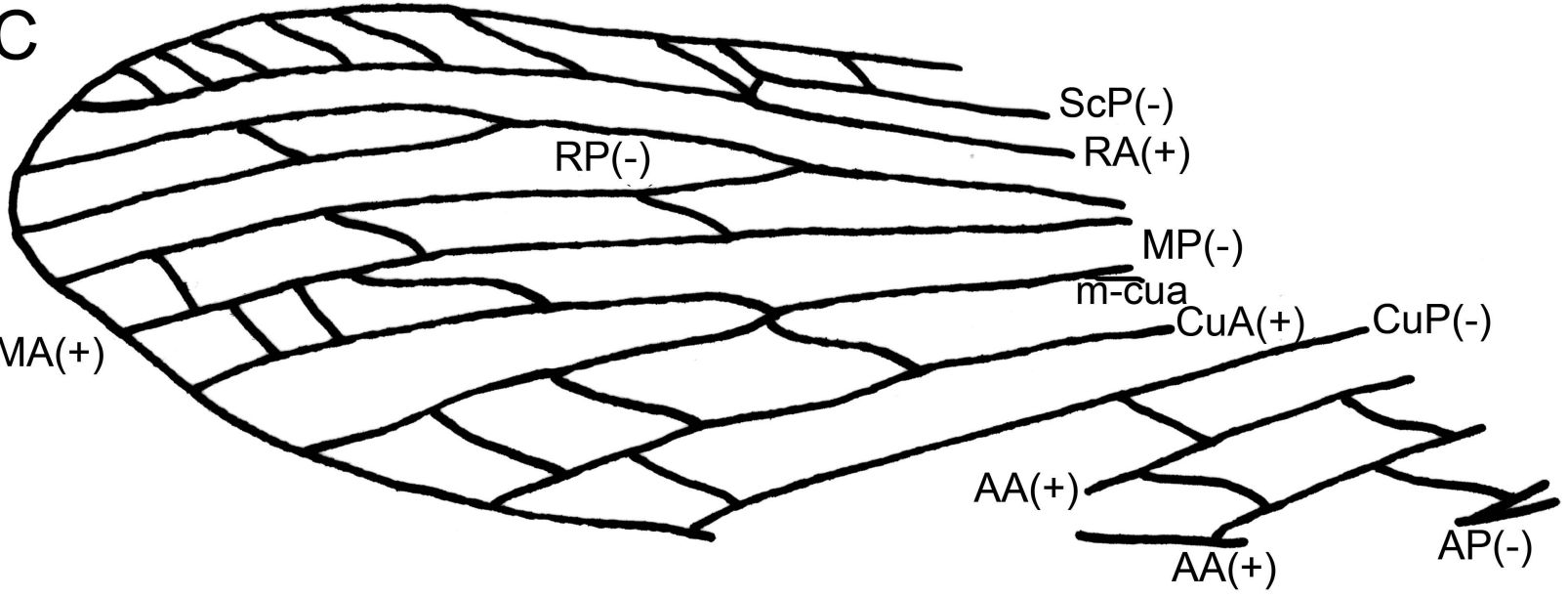

